\title{
S5ynthesis
}

International Scientific Conference of IT and Business-Related Research

\section{ENERGETSKA EFIKASNOSTI KAO USLOV ODRŽIVOG RAZVOJA LOKALNE ZAJEDNICE}

\author{
THE IMPORTANCE OF ENERGY EFFICIENCY FOR SUSTAINABLE DEVELOPMENT \\ OF THE LOCAL COMMUNITY
}

\author{
Duško Gvozdenović1, Dragan Marković ${ }^{2}$ \\ ${ }^{1}$ Univerzitet Singidunum, Danijelova 32, Beograd, Srbija \\ ${ }^{2}$ Univerzitet Singidunum, Danijelova 32, Beograd, Srbija
}

\begin{abstract}
Apstrakt:
Energetski sistem doživljava intenzivan stres. Posmatran, analiziran i implementiran kao koncept, globalna i lokalna potreba i kao filozofija održivog razvoja zajednice koja energetsku efikasnost tretira kao važnu dimenziju energetske stabilnosti, on predstavlja, ne samo nužnost, već $i$ jedini način da se prevaziđe energetska kriza. Trend primene mera energetske efikasnosti postaje značajan indikator održivog razvoja lokalne zajednice. Ovaj rad ima za cilj da koncept energetske efikasnosti analizira kroz nekoliko različitih sfera koje se odnose na dostupnost, pristupačnost, razvoj informacionih i komunikacionih tehnologija, društvenu uključenost, ekološku održivost, kao i zakonodavnu regulativu. Evaluacija do sada korišćenih mera za unapređenje energetske efikasnosti, kao jedan od metoda istraživanja koji je korišćen u ovom radu, treba sagledati kao kontinuiran proces koji podrazumeva, kako izbegavanje preterane upotrebe energije, tako i smanjenje energetskih gubitaka, ali i dosledno nadgledanje potrošnje energije u smislu smanjenja energetske intenzivnosti. Rezultati ovog istraživanja obuhvataju skup mera i aktivnosti, zasnovanih na doslednosti i primeni novih tehnologija, koje mogu obezbediti energetsku efikasnost i pozitivno uticati na održivi razvoj lokalne zajednice.
\end{abstract}

\section{Ključne reči:}

energetska efikasnost, energetska politika, dimenzije energetske bezbednosti, energetski indikatori održivog.

\section{UVOD}

Energetsku efikasnost treba shvatiti kao skup organizovanih aktivnosti koje se sprovode unutar energetskog sistema, u cilju smanjenja potrošnje ulazne energije, smanjenja emisije štetnih gasova i troškova energije, a bez promene kvaliteta izvršene usluge. Sama definicija ukazuje na kompleksnost problema koji proističe iz potreba da se povežu ljudi, procedure i tehnologije kako bi se došlo do trajnog povećanje energetske efikasnosti (Gvozdenac et al, 2014). Efikasno korišćenje energije je, već odavno, opšti interes koji prožima sve sfere društva, od globalnog do lokalnog nivoa. Značaj energetske efikasnosti u ekonomskom smislu je očigledan ako se uzme u obzir činjenica da troškovi energije obično čine 15-20\% bruto domaćeg proizvoda (BDP), a u lokalnim zajednicama budžetski troškovi za utrošenu energiju čine između 30-35\%.

Energetska efikasnost je definisana velikim brojem međusobno nezavisnih faktora, pa shodno tome ne postoji univerzalni indikator na osnovu kojeg je moguće proceniti energetsku efikasnost, ali trenutna situacija na pragu nove energetske krize nameće nužnost povećanja angažovanosti na implementaciji

\section{Abstract:}

The modern energy system is undergoing intense stress. Observed, analyzed and implemented as a concept, global and local necessity, and as a philosophy of sustainable development of the community which treats energy efficiency as an important dimension of energy stability, it is not only a necessity, but also the only way to overcome the energy crisis. Trend of implementation of energy efficiency measures is becoming an important indicator of sustainable development of local communities. This paper aims to analyze the concept of energy efficiency through several different spheres related to the availability, accessibility, development of information and communication technologies, social engagement, environmental sustainability and legislative regulation. The evaluation of measures used to improve energy efficiency, as one of the research method used in this study, should be viewed as a continuous process that involves both avoidance of the excessive use of energy, as well as reduction of energy losses, but also a consistent monitoring of energy consumption in terms of energy intensity reduction. The research results include a set of measures and actions, based on the consistency and application of new technologies, which can provide energy efficiency and have a positive bearing on sustainable development of the local community.

\section{Key words:}

energy efficiency, energy policy, energy security dimensions, energy indicators for sustainable development.

mera i aktivnosti koje će dovesti do energetski efikasnijih sistema. Indikatori energetske efikasnosti predstavljaju specifične energetske pokazatelje koji se koriste za definisanje potencijala uštede potrošnje energije kao i za utvrđivanje efekata sprovođenja mera energetske efikasnosti (Marković, 2010). Definisanje energetske efikasnosti uključuje razmatranje nekoliko različitih pristupa, ali pokriva širok spektar indikatora energetske potrošnje (Golušin et al, 2013).

U cilju postizanja globalnih (milenijumskih) ciljeva održivog razvoja, uloga energetske efikasnosti je neizostavna, a implementacija akcija i mera treba da bude koordinisana na svim nivoima, od međunarodnog, regionalnog do nacionalnog, a sve u cilju uspostavljanja pravnog/tehničkog/društvenog okvira za implementaciju energetske efikasnost. Koncept održivog razvoja možemo posmatrati kao dinamičan proces koji se prožima kroz tri sfere delovanja: ekonomsku održivost, održivost životne sredine i održivost društvenih sistema (Everett el al, 2010). Stvarna snaga za promene je na lokalnom nivou. Energetsku politiku treba razvijati na način da se ona može lako implementirati u infrastrukturama lokalnih zajednica, tj. u objektima od javnog značaja u javnim službama kao i industrijskim sistemima. 


\section{PLANIRANJE I POTENCIJALNE PREPREKE}

Lokalno energetsko planiranje kao višegodišnji kontinuirani proces, može biti važan alat koji će omogućiti lokalnim zajednicama da razviju sistem mera i aktivnosti na implementaciji i unapređenju energetske efikasnosti. Planiranje treba da omogući identifikaciju mehanizama putem kojih mogu da se usvajaju nove tehnologije kao i prakse procesa energetske efikasnosti, koje će se integrisati u postojeće tokove. Ovi mehanizmi mogu uključivati politike na poboljšanju energetske efikasnosti, strategije, akcione planove kao i razne izvore javnog ili privatnog investiranja.

Poboljšanje energetke efikasnosti lokalnih zajednica se može predstaviti kao skup mera i aktivnosti, i to kroz:

- Integraciju aktivnosti koje se sprovode u okviru servisa usluga i održavanja na lokalnom nivou (transport, infrastruktura, vodovod i kanalizacija, energetske potrebe i sl.) i to na način da se objedinjavanjem svih ulaznih parametara u okviru zajedničkog informaciono-komunikacionog sistema izvrši prezentacija dobijenih rezultata u formi izveštaja, bilansa ili uporednih statistika (engl. benchmarking).

- Kroz proces energetske efikasnosti treba da se omogući realizacija programa i procesa na novim poslovima u okviru lokalnih zajednica koji će dovesti do porasta učešća stručnog osoblja i uvođenje novih tehnologija.

- Implementaciju energetske efikasnost nužno dovodi do poboljšanja ekonomskih parametara lokalne zajednice i pospešuje konkurentnost.

- Implementacija mera i aktivnosti na procesu koje će nužno dovesti do povećane energetske sigurnosti, a samim tim će uticati na smanjenje energetske intenzivnosti na globalnom nivou.

- Smanjenje gasova „staklene bašta“ i drugih zagađivača vazduha je važan i neizostavan činilac zajednice koji je fokusiran, pre svega, na zaštiti životne sredine.

Shodno gore navedenim aktivnostima, a koje treba da sprovede lokalna zajednica u cilju postizanja energetskih efikasnih sistema, neophodno je preduzimanje sledećih aktivnosti:

- Implementaciju strategija i akcionih planova za poboljšanje energetske efikasnosti.

- Sprovođenje energetskog benčmarkinga za sve veće objekte lokalne zajednice.

- Podizanje svesti o nužnosti energetske efikasnosti, kao i vršenje konstantnih edukativnih procesa-radionica.

- Kupovine energetski efikasnih proizvoda najvišeg energetskog razreda.

- Korišćenje obnovljivih izvora u sektoru javne potrošnje.

- Podrška razvoju elektronski standardizovanih pristupa podacima kroz vid e-uprave.

- Istražiti programe energetske efikasnosti kroz različite mehanizme finansiranja.

Svakako, da će se u okviru implementacije i unapređenja procesa energetske efikasnosti lokalnih zajednica pojaviti prepreke koje se mogu manifestovati kao:

- Povećanje inicijalnih troškova lokalnog budžeta.

- Slaba tehnološka i edukativna informisanost.

- Izloženost riziku programa energetske efikasnosti usled ekonomske nerazvijenosti.

- Preveliki ili premali okviri za implementaciju mera i aktivnosti.

- Teškoće u kvantifikovanju i kvalifikovanju indikatora.

- Slaba interaktivna komunikacija svih aktera.
- Selektivnost monitoringa toka aktivnosti što dovodi do prekida kontinuiteta toka.

- Loša koordinacija među akterima unutar lokalne zajednice.

U cilju poboljšanja energetske efikasnosti neophodno je primeniti skup mera i aktivnosti koje će dovesti do uspostavljanja energetski efikasnih sistema u svim sektorima lokalne zajednice. Na slici 1. prikazan je tok aktivnosti koji se može predstaviti u pet kontinuiranih procesa, i to:

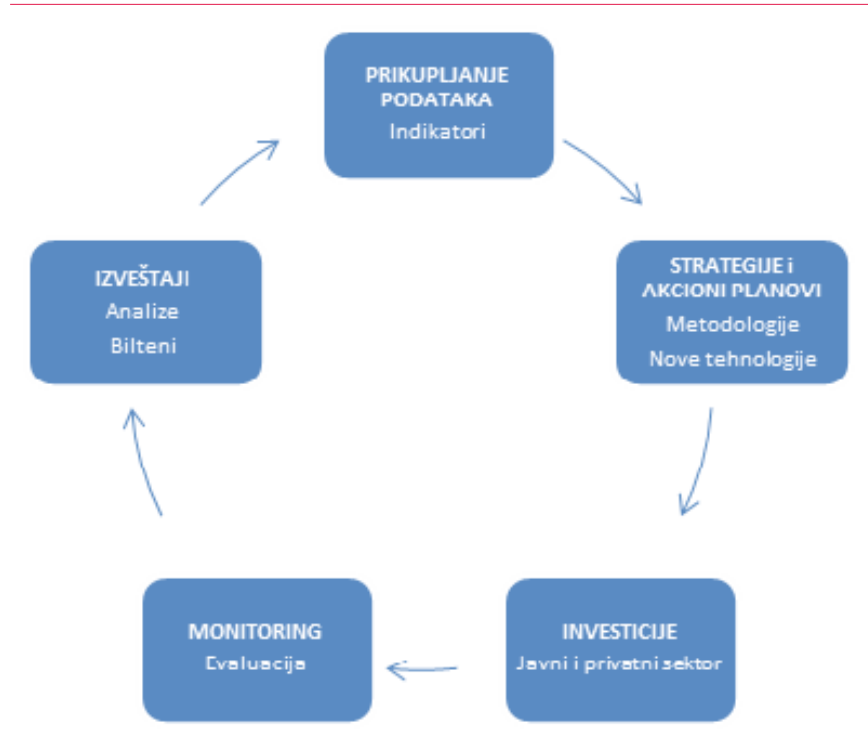

Slika 1. Tok aktivnosti na implementaciji energetske efikasnosti

1. Prikupljanje, ažuriranje i kvanitifikovanje podataka kroz sistemski pristup, treba da omogući dobijanje pravovremenih i referentnih indikatora koji će kreirati okvir za razvoj efikasnih strategija i politika energetske efikasnosti.

2. Na osnovu analize korišćenja energije, tržišta, tehnologija i ekonomskih mogućnosti, lokalne zajednice treba da formulišu strategije i akcione planove za poboljšanje energetske efikasnosti. Strategije u praksi kroz akcione planove treba da obezbede:

- Metodološke pristupe.

- Razvoj mernih i verifikacionih protokola.

- Edukativne radionice.

- Nova tehnološka-komunikaciona-informaciona rešenja.

- Pristup informacijama i društvenu inkluziju.

3. Privatne i javne i investicije u energetsku efikasnost kroz izgradnju energetskih kapaciteta (posebno OIE) u okvirima standardizovanih protokola (IEA, 2011).

4. Praćenje, sprovođenje i evaluaciju politika i mera kroz periodičnu energetsku nadogradnju kroz politiku mera energetske efikasnosti u svim sektorima. Politika treba da se rukovodi sledećim principima :

- Efikasnost procesa koji treba treba ocenjivati tokom i posle realizacije, uz konstantan monitoring.

- Evaluaciju kroz transparentan proces mera i aktivnosti.

5. Na osnovu rezultata monitoringa, a u okviru evaluacije tokova energetske efikasnosti, neophodno je izraditi izveštaje u formi biltena-bilansa koji će postati ulaznikorektivni indikatori za procenu nivoa energetki efikasne lokalne zajednice. 


\section{REZIME}

Uloga energetske efikasnosti se razlikuje od zemlje do zemlje, u smislu zakonske regulative, ljudskih potencijala, razvijenosti informaciono-komunikacionih tehnologija, stepena društvene inkluzije, politike cena energije i energenata i sl. Dosadašnji rezultati ukazuju da je put ka poboljšanju energetske efikasnosti najmanje skupa opcija. Mnoga potencijalna rešenja za uštedu energije su već lako dostupna i danas su to integrisane i dokazane tehnologije. Kroz permanentne programe edukacije i usavršavanja koje će kroz nove informaciono komunikacione tehnologije dovesti do bržeg pristupa informacijama o toku i nivou održivog razvoja, lokalna zajednica je u obavezi da konstantno vrši energetsku nadgradnju svih raspoloživih rešenja kao i implementaciju novih, koje će dovesti do efikasnog okruženja koje želi da bude održivo u svim sferama društvenog delovanja.

\section{LITERATURA}

Everett, B., Godfrey, B., Peake S., \& Ramage, J. (2012). Energy System and Sustainability. New York: Oxford University Press.

Golušin, M., Dodić, S., \& Popov, S. (2013). Sustainable Energy Management. Amsterdam: Elsevier.

Gvozdenac, D.D., et al. (2014). Serbian Energy Efficiency Problems. Thermal Science, 18(3), 683-694. DOI 10.2289/TSCI1403683G.

International Energy Agency. (2011). 25 Energy Efficiency Policy: Recommendations. Preuzeto 3. februara 2015, sa https://www.iea. org/publications/freepublications/publication/25recom_2011. pdf

International Energy Agency. (2014). World Energy Outlook 2014. Preuzeto 3. februara 2015, sa http://www.worldenergyoutlook.org/publications/weo-2014/

Marković, D.S. (2010). Procesna i energetska efikasnost. Beograd: Univerzitet Singidunum 